\title{
Lightweight adjustable partition system: Evaluation of resistance to horizontal loads and functional failure from impacts
}

\section{Sistema de partición ligera ajustable: Evaluación de la resistencia a cargas horizontales y daños funcionales por impacto}

$\underline{\text { P. Mendonça }}^{(*)}$, M. Macieira ${ }^{(* *)}$, L. F. Ramos ${ }^{(* * *)}$

\section{ABSTRACT}

This paper presents and discusses the results of the serviciability and use condition tests carried on an innovative solution for partitions, designated AdjustMembrane developed within a research project. The proposed system is a modular non-loadbearing wall, tensioned between the pavements and ceiling slabs, which are used as anchoring elements. It allows several advantages, related with the weight reduction to achieve a good sustainable performance, such as the reduction of construction costs, energy, and materials, and it is easy to recycle and to reuse, allowing self-construction. Apart from a general presentation of the partition technology, this paper presents and discusses the results of experimental tests carried out. From the results obtained, it is possible to conclude that the solution fulfils the requirements for this typology of wall in terms of resistance to horizontal loads induced by soft and hard body impacts.

Keywords: Lightweight construction; adjustable; non-loadbearing partition wall; fibrous materials; mechanical behaviour; experimental tests; laboratorial prototype; impact tests.

\section{RESUMEN}

En este trabajo se presentan y discuten los resultados de ensayos de condiciones de servicio y seguridad de uso de una solución innovadora para particiones interiores, designada por AdjustMembrane y desarrollada en un proyecto de investigación. El sistema propuesto es una solución de partición modular no estructural, tensada entre los forjados de piso y de techo, que se utilizan como elementos de anclaje. Permite varias ventajas, relacionadas con la reducción de peso para lograr buenos indicadores de sostenibilidad, tales como la reducción de los costos de construcción, energía y materiales. Es fácil de reciclar y reutilizar, lo que permite la auto-construcción. Además de una presentación general de la tecnología de pared desarrollada, se presentan y discuten los resultados de algunos ensayos experimentales efectuados. A partir de los resultados obtenidos fue posible concluir que la solución cumple con los requisitos de resistencia a cargas horizontales y daños funcionales por impacto de cuerpo duro y blando, adecuado para esta tipología de tabique.

Palabras clave: Construcción ligera; ajustable; tabique no estructural; materiales fibrosos; comportamiento mecánico; pruebas experimentales; prototipo de laboratorio; resistencia al impacto.

\author{
(*) Lab2PT - Univiversity of Minho, Guimarães (Portugal). \\ ${ }^{(* *)}$ C-TAC - Univiversity of Minho, Guimarães (Portugal). \\ (***) ISISE - University of Minho, Guimarães (Portugal). \\ Persona de contacto/Corresponding author: mendonca@arquitectura.uminho.pt (P. Mendonça).
}

Cómo citar este artículo/Citation: Mendonça, P., Macieira, M., Ramos, L. F. (2015). Lightweight adjustable partition system: Evaluation of resistance to horizontal loads and functional failure from impacts. Informes de la Construcción, 67(539): e102, doi: http:// dx.doi.org/10.3989/ic.13.166.

Licencia / License: Salvo indicación contraria, todos los contenidos de la edición electrónica de Informes de la Construcción se distribuyen bajo una licencia de uso y distribución Creative Commons Reconocimiento no Comercial 3.o. España (cc-by-nc). 


\section{INTRODUCTION}

The permanent evolution and mutation of life styles and family units have been conducting to the rethink of living spaces and to a growing need for more evolutionary and adaptable dwellings (1) (2). It can be verified that a great portion of houses don't accomplish that premise nowadays. This happens because the technological and constructive solutions used on conventional interior partitions, such as hollow brick or plasterboard with metallic frame systems, are static and difficult to readapt without a significant cost due to the specialized work required and material loss during the assembly process. This problem reveals to be more important in the refurbishment of existing buildings, but also when new buildings are conceived - knowing that, in future, the need of reorganizing interior space will become as difficult as today.

Growing necessity to save material and energetic resources, allied to a growing concern over the environmental issues and incertitude on the evolution of the economy, has impelled minimalist-approaches to Architecture and Engineering, reducing to the minimum necessary expression the constructive elements. These approaches, by some authors called "Light-tech" (3) and Eco-tech (4), bets on the introduction of more materially and energetically efficient solutions.

A partition is a thin element built to divide the indoor space into rooms or other compartments. Generally, walls are nonload bearing. For a load-bearing walls, strength is an important factor of design. A partition, on the other hand, needs only to be strong enough to support itself under normal conditions of service and to fulfil several requirements related to fire, air quality, dampness, safety in use, sound insulation, among others (see also Table 1 and Table 2). One of the main safety requirements of a partition is to have the necessary mechanical resistance to support accidental impacts resulting from the occupation of the building without injuring the occupants (5).

Addis \& Schouten (6) refer that partitions have emerged as building sub-systems, as result of several factors, including the development of frame construction where internal walls are no longer required to have a load-bearing function. Due to emergent aspects like the speed of organizational and technological change, the increased number and complexity of services to be accommodated, the quality and aesthetic issues and the need for acoustic separation of areas, the contemporary internal partitions present nowadays new requirements.

Only recently, the construction market has being given clear signs for the systematic use of lightweight partition solutions, such us drywalls. Besides the weight, the drywalls have the advantage of being easier to incorporate the installations, contrarily to the usual brick masonry walls, in which groves must be made to include electrical, communication and hydraulic installations. The reduction of the waste during the construction represents a significant advantage in the economic and environmental point of view as it eliminates or deeply reduces the costs of transportation of wastes and contributes to avoid the accumulation of wastes in sanitary landfills.

In buildings, the performance requirements of non-load bearing partition walls result on the complementarity between the wall and coating. In some situations the coating is executed at the factory, so it is not possible to distinguish between rough wall and its coating. However, on Adjust-
Membrane solution the coating is detachable and applied on site. It is an important factor in the performance of certain functions. The rough wall will have a greater contribution to the stability, mechanical strength, security (against the risk of human or animal intrusion), hygrothermal and acoustic comfort requirements (7). At the same time, the cladding will be primarily responsible for meeting the contact security requirements, appearance, surface regularity, visual comfort, tactile comfort and hygiene. Table 1 and 2 shows the list of performance requirements for internal partitions.

The present paper addresses an innovative lightweight adjustable partition technology designated by AdjustMembrane, conceived within a research project. There is an European patent application for this technology. Apart from this Section of introduction, Section 2 presents with detail the AdjustMembrane solution in terms of shape, geometry and materials; Section 3 discusses the associated construction technology; Section 4 presents the setup for horizontal load impact tests to evaluate the safety in use and serviceability; Section 5 presents the overall results analysis and the discussion; and Section 6 the conclusions and remarks.

Table 1. Requirements for an interior partition wall (8).

\begin{tabular}{|l|l|l|}
\hline \multicolumn{1}{|c|}{ Structural } & \multicolumn{1}{|c|}{ Functional } & \multicolumn{1}{c|}{ Execution } \\
\hline Stability & Acoustic insulation & $\begin{array}{l}\text { Assembling and } \\
\text { adaptability }\end{array}$ \\
\hline Traction resistance & Thermal insulation & Doors placement \\
\hline Impact resistance & Fire insulation & $\begin{array}{l}\text { Possibility of plac- } \\
\text { ing facilities }\end{array}$ \\
\hline Abrasion resistance & Water tightness & Portability \\
\hline & Air tightness & \\
\hline & Tactile comfort & \\
\hline & Cleanability & \\
\hline & & \\
\hline
\end{tabular}

\section{ADJUSTMEMBRANE SOLUTION}

The lightweight partition wall solution with greater implementation in the Portuguese market is the plasterboard solution with a sub structure of light gauge frame profiles. The AdjustMembrane solution differs from this lightweight reference solution because (a) it can weight even less; (b) it is tensioned; (c) it allows easy disassembly (because of its mechanical fixings); (d) easy integration of water, electrical and other piping systems without damaging the coating; and (e) it allows spatial reconfiguration by entirely reusing components. In a scenario of disassembly, plasterboard solution only permits the reuse of structure but not for coating (6) and the space reconfiguration becomes very constrained. AdjustMembrane partition system is built on tensioned supporting straps and by using a grid, a flexible core and a detachable coating.

AdjustMembrane solution allows the integration of installations in its core avoiding the use of acoustic and thermal insulation of the pipes. The introduction of the infra-structures reveals to be relatively easy in real conditions. The positioning of the water pipes is possible by introducing these in the perforations previously designed for the grid and insulation core. This task revealed to be reasonably simple and fast. 
Table 2. Overview of performance requirement for non-load bearing partition kits, adapted from (5).

\begin{tabular}{|c|c|c|}
\hline $\begin{array}{c}\text { Essential } \\
\text { requirements }\end{array}$ & Sub-requirements & Methods of verification \\
\hline \multirow[t]{4}{*}{ Safety in case of fire } & Reaction to fire & Test methods for the Euroclasses A - F developed by CEN. \\
\hline & \multirow[t]{3}{*}{ Fire resistance } & EN 1363-1: Fire Resistance - General Requirements. \\
\hline & & EN 1363-2: Fire Resistance Tests - Part 2: Alternative and Additional Procedures \\
\hline & & EN 1364-1: Fire Resistance Tests on Non-loadbearing Elements in Buildings - Part 1: Walls \\
\hline \multirow{6}{*}{$\begin{array}{l}\text { Hygiene, health } \\
\text { and the environment }\end{array}$} & \multirow{4}{*}{$\begin{array}{l}\text { Release of formal- } \\
\text { dehyde, asbestos } \\
\text { (content), pentachlo- } \\
\text { rophenol and other } \\
\text { dangerous substances }\end{array}$} & Only for kits with wood-based panels \\
\hline & & EN 120:1993, Wood based panels - Determination of formaldehyde content - Extraction method called the perforator method \\
\hline & & EN 717-2:1995, Wood-based panels - Determination of formaldehyde release - Part 2: Formaldehyde release by the gas analysis method \\
\hline & & EN 717-3:1997, Wood-based panels - Determination of formaldehyde release - Part 3: Formaldehyde release by the flask method \\
\hline & $\begin{array}{l}\text { Water vapour } \\
\text { permeability }\end{array}$ & EN 12086:1997, Thermal performance of buildings and building components - Determination of water vapour transmission properties. \\
\hline & Water permeability & Not relevant. (Covered by technical specifications on the watertightness or water resistance of wall coverings.) \\
\hline \multirow[t]{9}{*}{ Safety in use } & \multirow{6}{*}{$\begin{array}{l}\text { Resistance to horizon- } \\
\text { tal and eccentric loads }\end{array}$} & Resistance to structural damage from soft body impact load - $50 \mathrm{~kg}$ bag \\
\hline & & $\begin{array}{l}\text { ISO 7892:1988, Vertical Building Components - Impact Resistance - Impact Bodies and General Test Procedures and ISO/DIS 7893:1990, } \\
\text { Performance Standards in Building - Partitions made from Components - modifications as described in Annexes B, C and D to the } \\
\text { ETAGo03 Guideline. }\end{array}$ \\
\hline & & Resistance to structural damage from hard body impact load - $1 \mathrm{~kg}$ steel ball \\
\hline & & $\begin{array}{l}\text { ISO 7892:1988, Vertical Building Components - Impact Resistance - Impact Bodies and General Test Procedures and ISO/DIS 7893:1990, } \\
\text { Performance Standards in Building - Partitions made from Components - Impact Resistance Tests, with amendments and modifications } \\
\text { as described in Annexes B, C and D to the ETAGo03 Guideline. }\end{array}$ \\
\hline & & Resistance to structural damage from eccentric vertical load \\
\hline & & $\begin{array}{l}\text { Testing of partitions for support of heavy eccentric vertical downward load is performed as described in ISO/DIS 8413:1990, Performance } \\
\text { Standards in Building - Partitions made from Components - Tests for Ability to withstand Suspended Static Loads, with amendments and } \\
\text { modifications as described in Annexes B, C and D to the ETAGo03 Guideline. }\end{array}$ \\
\hline & \multirow{3}{*}{$\begin{array}{l}\text { Safety against } \\
\text { personal injuries by } \\
\text { contact }\end{array}$} & $\begin{array}{l}\text { Geometry: The geometry of positioning of specific features is a function of the works and, therefore, cannot be dealt with by testing or as- } \\
\text { sessment of the product specification. }\end{array}$ \\
\hline & & Existence of sharp or cutting edges: For the assessment of the presence of sharp or cutting edges, no tests are necessary. \\
\hline & & Nature of surfaces: Assessment of the nature of the surface does not require testing. \\
\hline \multirow[t]{3}{*}{$\begin{array}{l}\text { Protection against } \\
\text { noise }\end{array}$} & $\begin{array}{l}\text { Airborne sound } \\
\text { insulation }\end{array}$ & $\begin{array}{l}\text { EN/ISO 140-3:1995, Acoustics - Measurement of sound insulation in buildings and of building elements - Part 3: Laboratory measure- } \\
\text { ments of airborne sound insulation of building elements. }\end{array}$ \\
\hline & \multirow[t]{2}{*}{ Sound absorption } & EN 20354:1993, Acoustics - Measurement of sound absorption in a reverberation room \\
\hline & & $\begin{array}{l}\text { EN/ISO 354/A1:1997, Acoustics - Measurement of sound absorption in a reverberation room - Amendment 1: Test specimen mountings } \\
\text { for sound absorption tests. }\end{array}$ \\
\hline \multirow[t]{9}{*}{$\begin{array}{l}\text { Energy economy } \\
\text { and heat retention }\end{array}$} & \multirow[t]{7}{*}{ Thermal resistance } & $\begin{array}{l}\text { Thermal insulation - EN/ISO 6946:1996, Building components and building elements - Thermal resistance and thermal transmittance - } \\
\text { Calculation method. }\end{array}$ \\
\hline & & Testing of thermal resistance is performed as described in: \\
\hline & & $\begin{array}{l}\text { EN/ISO 8990: November 1995, Thermal Insulation - Determination of steady-state thermal transmission properties - Calibrated and } \\
\text { guarded hot box. }\end{array}$ \\
\hline & & $\begin{array}{l}\text { EN 12667:1996, Building materials - Determination of thermal resistance by means of guarded hot plate and heat flow meter methods - } \\
\text { Products of high and medium thermal resistance. }\end{array}$ \\
\hline & & $\begin{array}{l}\text { EN 12939:1997, Building materials - Determination of thermal resistance by means of guarded hot plate and heat flow meter methods - } \\
\text { Thick products of high and medium thermal resistance. }\end{array}$ \\
\hline & & $\begin{array}{l}\text { EN/ISO 10211-1:1995, Thermal bridges in building constructions - Part 1: Heat flows and surface temperatures - General calculation } \\
\text { methods }\end{array}$ \\
\hline & & $\begin{array}{l}\text { EN/ISO 10211-2:1995, Thermal bridges in building constructions - Part 2: Heat flows and surface temperatures - General calculation of } \\
\text { linear thermal bridges. }\end{array}$ \\
\hline & \multirow[t]{2}{*}{ Thermal inertia } & To make it possible to calculate the thermal inertia of the partition, information on the following properties of the partition shall be given: \\
\hline & & $\begin{array}{l}\text { - total mass per unit area (in } \mathrm{kg} / \mathrm{m}^{2} \text { ), density of materials used (in } \mathrm{kg} / \mathrm{m}^{3} \text { ), heat capacity of materials used (in } \mathrm{J} / \mathrm{kg} \mathrm{K} \text { ), thermal transmit- } \\
\text { tance of materials used (in } \mathrm{W} / \mathrm{m}^{2} \mathrm{~K} \text { ). }\end{array}$ \\
\hline \multirow{11}{*}{$\begin{array}{l}\text { Aspects of durability } \\
\text { and serviceability }\end{array}$} & \multirow{10}{*}{$\begin{array}{l}\text { Robustness and } \\
\text { rigidity }\end{array}$} & Resistance to functional failure from soft body impact load $-50 \mathrm{~kg}$ bag \\
\hline & & $\begin{array}{l}\text { ISO 7892:1988, Vertical Building Components - Impact Resistance - Impact Bodies and General Test Procedures and ISO/DIS 7893:1990, } \\
\text { Performance Standards in Building - Partitions made from Components - modifications as described in Annexes B, C and D to the } \\
\text { ETAGoo3 Guideline. }\end{array}$ \\
\hline & & Resistance to functional failure from hard body impact load $-0.5 \mathrm{~kg}$ steel ball \\
\hline & & $\begin{array}{l}\text { ISO 7892:1988, Vertical Building Components - Impact Resistance - Impact Bodies and General Test Procedures and ISO/DIS 7893:1990, } \\
\text { Performance Standards in Building - Partitions made from Components - Impact Resistance Tests, with amendments and modifications } \\
\text { as described in Annexes B, C and D to the ETAGo03 Guideline }\end{array}$ \\
\hline & & Resistance to functional failure from eccentric vertical load \\
\hline & & $\begin{array}{l}\text { ISO/DIS 8413:1990, Performance Standards in Building - Partitions made from Components - Tests for Ability to withstand Suspended } \\
\text { Static Loads, with amendments and modifications as described in Annexes B and C to the ETAGo03 Guideline }\end{array}$ \\
\hline & & Resistance to functional failure from point loads parallel or perpendicular to the surface \\
\hline & & $\begin{array}{l}\text { ISO/DIS 8413:1990, Performance Standards in Building - Partitions made from Components - Tests for Ability to withstand Suspended } \\
\text { Static Loads. }\end{array}$ \\
\hline & & Rigidity of partitions to be used as a substrate for ceramic tiling \\
\hline & & Annex D of ETAGoo3 Guideline. \\
\hline & $\begin{array}{l}\text { Resistance to } \\
\text { deterioration } \\
\text { (Physical, Chemical } \\
\text { and Biological agents) }\end{array}$ & Described in ETAGoo3 \\
\hline
\end{tabular}




\subsection{Shape and geometry}

The developed partition system presents an innovative shape and geometry and intends to be used in non-loadbearing partitions. The definition of the geometry was based on four main ideas, namely: 1) obtaining a partition system that results in an easy construction technology and thus decrease construction times; 2) to be possible to install infra-structures during construction of the walls and thus reduce the production of wastes; 3) obtaining a partition system that function in tensile and not in compression with lightweight materials; and 4) to permit portability and multiple assembling/disassembling.

The panel is composed by cubic modular components, equivalent to an outlet box, and is composed of two equal halves (Figure 1), that is connected by male/female fixings, and present vertical and horizontal perforations, which are adequate to an efficient integration of the infra-structures, as can be seen on Figure 1e).

\subsection{Materials}

Besides the conception of the geometry and shape of the partition, some details of materials are presented here. The process of selecting materials for the interior partition is a challenging task. In previous studies it was made a material selection to the sandwich panel configuration attending functional, economic and environmental demands for AdjustMembrane design. Within this project the functional performance (acoustic and thermal) and sustainable assessment profile were already described in detail on previous publications (9) (10) (11).

AdjustMembrane partition system constitutes a modular building solution of a non-load bearing wall, tensioned between the pavements and ceiling slabs that are used as anchoring elements. It is important to understand at which part of the partition is able to bear impact loads to assign it a certain use. Table 3 presents the material's mechanical properties used in the interior walls.

\section{CONSTRUCTION TECHNOLOGY OF THE ADJUSTMEMBRANE PARTITION WALL}

Unlike the conventional partitions, in which the supporting elements operate generally in compression, the proposed solution is tensioned between the floor and ceiling to ensure the stability of the system. The assembling sequence of the AdjustMembrane wall prototype ( $1.2 \mathrm{~m}$ length by $2.8 \mathrm{~m}$ height) used in the experimental testing campaign is shown in Figure 1.

The construction process is directly related to the aim of the efficient introduction of the infra-structures in the partitions and easy assembly and disassembly. Therefore, the constructive process is composed of five steps: 1) fix ratchet tie down polyester straps (Figure 1a); 2) laying of the first grid and core leaf up to a height corresponding to the positioning of the infra-structures (Figure $1 \mathrm{~b}$ ); 3) positioning of the infra-structures; 4) laying of the second layer and connection trough engaging connections (Figure 1e); and 5) if the core material do not have attached the coating layer, this should be engaged.

Table 3. Material's mechanical properties.

\begin{tabular}{|l|c|c|c|}
\cline { 2 - 4 } \multicolumn{1}{c|}{} & Density & $\begin{array}{c}\text { Tensile stren- } \\
\text { gth/Force }\end{array}$ & $\begin{array}{c}\text { Elastic modulus/ } \\
\text { Stiffness }\end{array}$ \\
\hline Polyurethane (PU) foam core & $40 \mathrm{~kg} / \mathrm{m}^{3}$ & - & $22 \mathrm{kPa}$ \\
\hline Rigid Polyvinyl chloride (PVC) grid & $1400 \mathrm{~kg} / \mathrm{m}^{2}$ & $45 \mathrm{MPa}$ & $3378 \mathrm{MPa}$ \\
\hline Rachet + straps & - & $50 \mathrm{kN}$ & $395 \mathrm{kN} / \mathrm{m}$ \\
\hline
\end{tabular}

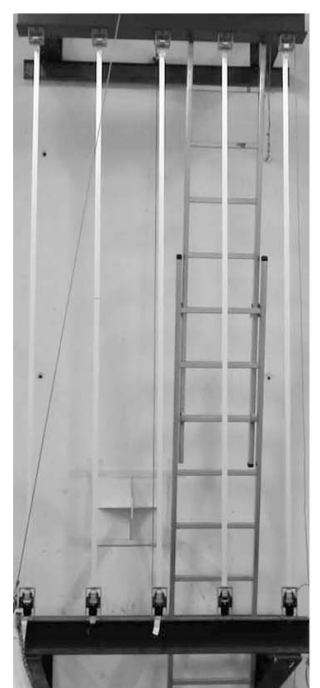

(a)

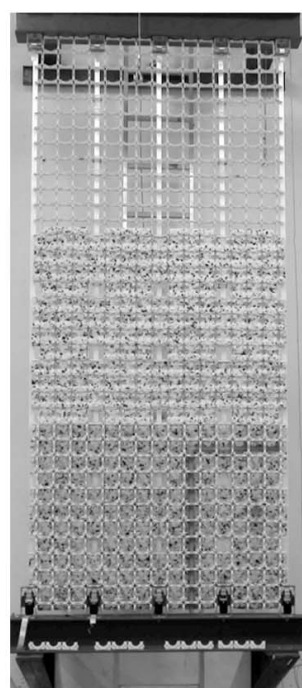

(b)

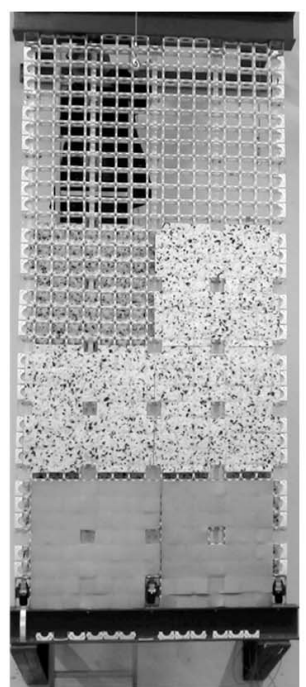

(c)

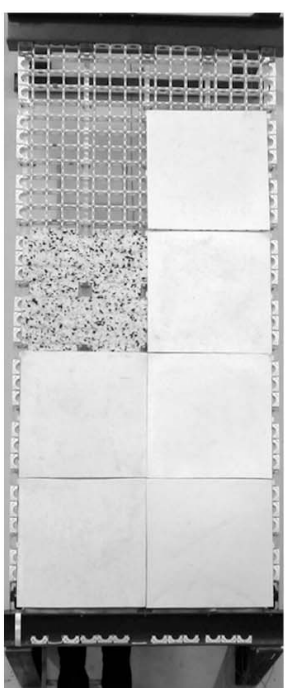

(d)

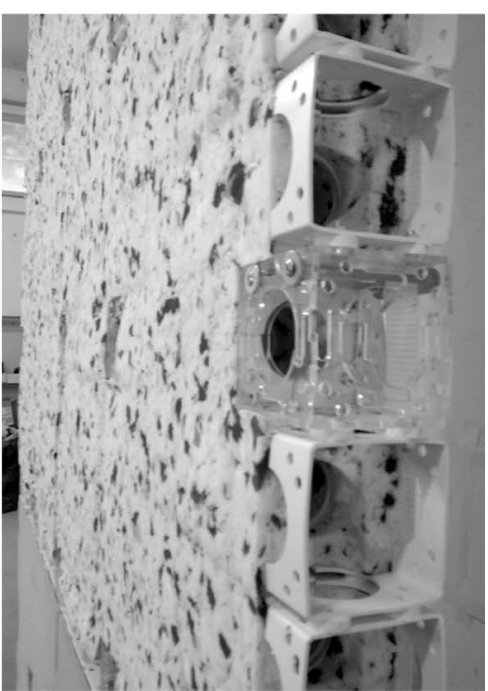

(e)

Figure 1. Sequence of AdjustMembrane prototype assembling. 
As other non-loadbearing partitions, the presented solution can be applied as inner panels of double walled façade solution and takes on the assumption that the fastening system should be applied at locals where elements (floor, ceiling and walls) positioned at its boundary must be of rigid type (concrete, steel or wood), that is practically undeformable and enable a good fixing of the resistant elements of the partition.

The present solution provides a solution composed by light modular panels, with dimensions of $600 \times 600 \mathrm{~mm}^{2}$ or higher allowing easy transportation and dry in situ assemblage.

\subsection{Modular components}

AdjustMembrane core system is composed by grid and insulation modular components. The insulation is constituted by malleable fibrous material with grooves whose geometry allows the integration of pipes, as previously mentioned. The grid and the core are composed by modules that can be subtracted or added anytime to allow the integration of facilities such as water or electrical pipes and switches or outlets, without panel damaging (Figure 1e).

AdjustMembrane presents a coating in the external faces of the core that are assembled by fitting to the core grid (Figure 1b). The panel coating used on experimental test was polyester hot pressed bat it is possible to use polymers, textile materials, metal sheets or composite materials with reinforcing fibbers, or other types of rigid panels or films (fibbers, polymers or composites).

An over-coating may also be placed on site. The over-coatings to be applied can be fabrics or films. A tensioned PVC membrane attached to a frame system is available in the market, with specific profiles which make the adjustment of the membrane. Membranes are also available on the market. The most common are: PVC, PTFE, silicone, and vinyl with or without reinforcing structure (usually woven polyester or fibreglass). There may also be added OSB panels, MDF, plywood, etc., mechanically fixed by "Velcro" or other fastening system, like quick coupler type which does not compromise the disassembly. In spite of hamper the easy disassembly desired, it admits the possibility of using more conventional over-coatings such as plaster, mortar, particularly with synthetic linkers (e.g. acrylic).

\section{IMPACT RESISTANCE OF ADJUSTMEMBRANE SYSTEM USING A LABORATORIAL PROTOTYPE}

This section presents and discusses the results of an experimental campaign designed for the mechanical validation of AdjustMembrane partition in terms of resistance to horizontal loads and functional failure from hard and soft body impacts.

\subsection{Assessment of the impact loading: Method and Calculations}

The European guidelines for technical approval of interior partition kits (5) define two states in relation to which the resistance to impact should be verified, namely the state which foresee mechanical damage and the state that ensure adequate behaviour under service loads. For each state distinct levels of loading, which are associated to distinct categories of use, are defined from the loading area categories stated in
EC1 (12). The categories of use are: Category A (areas of residential use); Category B (offices); Category C, which foresees areas with the possibility of people concentration; Category $\mathrm{D}$ (shopping areas); and Category E, where the concentration of goods is probable. In (5), the categories of use I e II include the previous categories A and B, the category of use III includes the zones $\mathrm{C} 1$ to $\mathrm{C} 4, \mathrm{D}$ and $\mathrm{E}$ and the category of use IV includes the zones $\mathrm{C}_{5}, \mathrm{~A}, \mathrm{~B}, \mathrm{C} 1-\mathrm{C}_{4}, \mathrm{D}$ and $\mathrm{E}$. The definition of the categories I to IV relates to the need of protection of the walls, with the risk to occur accidents and to exist improper use. The present partition kit solution was mainly conceived to be used on Categories A and B (I and II, respectively).

At this point, it should be referred that the guidelines for interior partition kits (5) also recommends carrying out mechanical tests for eccentric vertical load and horizontal linear static load. Due to the nature of the partition, namely its flexibility or low bending stiffness, the two additional mechanical tests were not carried out, since the concept of the AdjustMembrane partition in the present version cannot be directly compared to traditional partitions in this parameter. Further research on prototypes using other materials on the coating and/or grid of this solution would be necessary to improve the response of this partition concept concerning these issues, which was out of the scope on the present work. Additionally, all the test procedures were adjusted to the available prototype size, which was built mainly to analyse the assemblage phases and the workability of the AdjustMembrane partition. At this moment there are no specific standards to carry out impact tests. The impact tests can be made following the recommendations of (13) and (14).

Impact tests were carried out on a prototype of $1.2 \mathrm{~m}$ length, $2.8 \mathrm{~m}$ height and $0.07 \mathrm{~m}$ thickness. The dimension of this prototype is smaller than the dimension preconized on the guidelines (5), due to the fact that it is considered that the prototype was built using a rigid steel frame in one side, representing the position for a door or other discontinuities in its surface, such as a window. The prototype wall to the left of this rigid frame was built according to the construction technology described previously. The connection to the steel structure has been defined by screwing the solution to the metal support. The impact simulation tests carried out at this phase considering the lightweight interior partition kit composed by a PVC grid (constituted by modular components with mechanical male/female fixings between them), polyurethane foam and PVC rigid cover layer. These were the materials with which was possible to build the prototype in this phase, and the main objective of the prototype in this phase was to test the assembling process. The use of other materials in a bigger wall size will be considered for future research, as soon as there will be companies interested in producing the technology in a bigger scale, what is in the present moment under negociation.

\subsection{Impact tests planning}

According to the recommendations (13), (15) and (16), two distinct types of impact resistances should be considered, namely the hard body and soft body impact tests, aiming at simulating the resistance of the wall to the projection of objects or the collision between users and partitions. The hard body impact is materialized with a steel sphere, whereas the soft impact is materialized by the collision of a bag with a specified geometry and mass. The steel spheres should have 
diameters of $50.0 \mathrm{~mm}$ and $63.5 \mathrm{~mm}$ and weights of $0.5 \mathrm{~kg}$ and $1.0 \mathrm{~kg}$, respectively, to verify the safety in use and the partition serviceability, respectively (see Figure 2a). To obtain the behaviour of the wall to soft body impact, a bag with a specified geometry (13) should be used. The bag should be filled with glass spheres of $3 \mathrm{~mm}$ diameter in a total mass of $50 \mathrm{~kg}$ (see Figure 2b).

As already mentioned, the impact resistance of a partition kit consists of its ability to withstand impact loads after which it is possible to maintain its normal use. The resistance to soft body impact load is associated to certain impact energy, $E_{i}$, given by the expression:

$$
E_{i}=g \times h \times m
$$

where $h$ is the drop height of the body, $g$ is the gravity acceleration $\left(9.81 \mathrm{~m} / \mathrm{s}^{2}\right)$, and $m$ is the mass of the body. The principle involved in this procedure is that the potential energy has the possibility to be converted in kinetic energy. Depending on the category of use, different impact energies are defined by varying the drop height of the bag, as shown on Figure 2. (a)

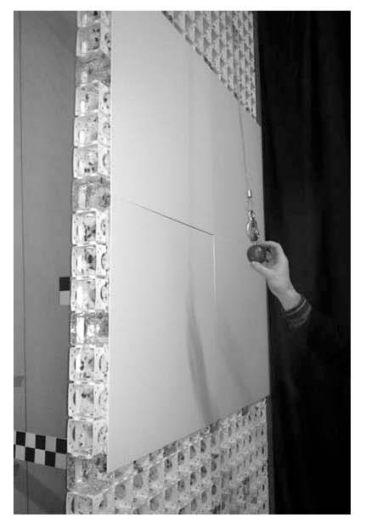

(b)

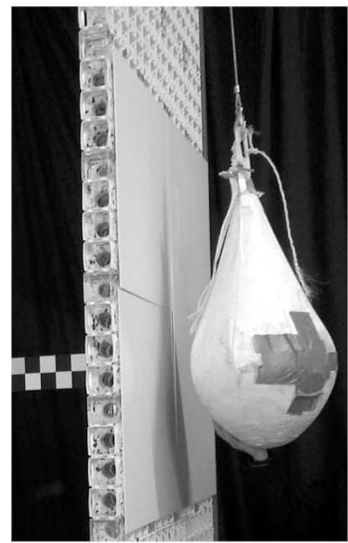

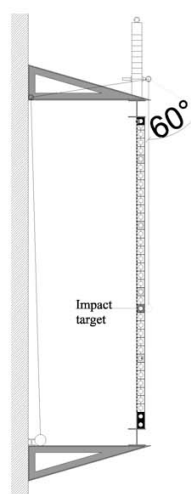

Impact test_Hard body_1 kg_10 Nm Safety in use

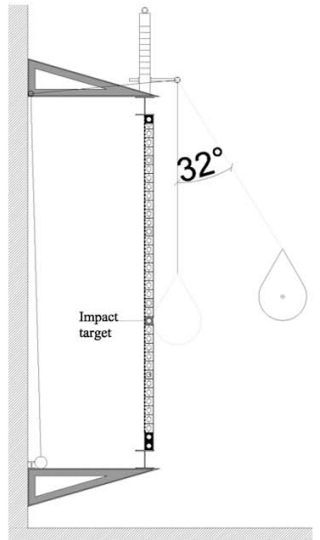

Impact test_Soft body_50 kg_10o Nm Safety in use

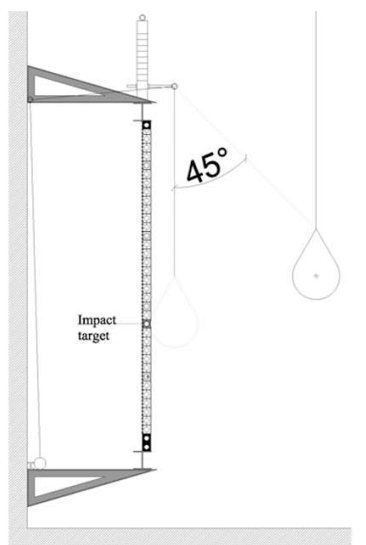

Impact test_Soft body_5o kg_200 Nm Safety in use

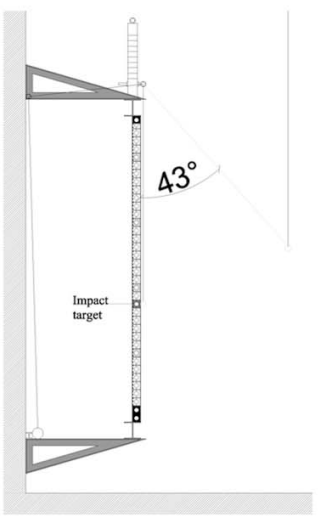

Impact test_Hard body_0.5 kg_2.5 Nm Serviceability

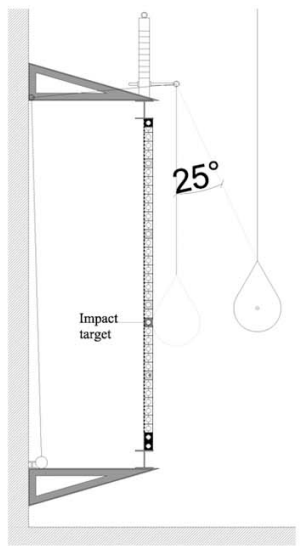

Impact test_Soft body_50 kg_6o Nm Serviceability

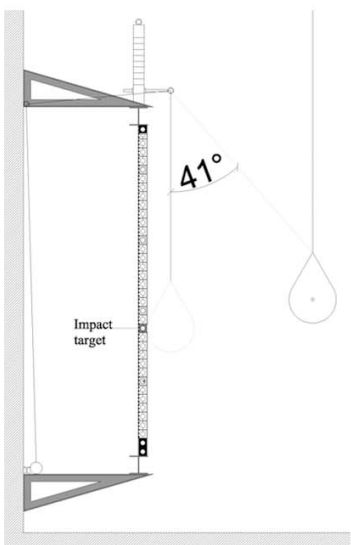

Impact test_Soft body_50 kg_120 Nm Serviceability

Figure 2. Details of impact tests: (a) Set up of impact tests with hard body - steel spheres; (b) Set up of impact tests with soft body. 
The serviceability impact resistance was obtained for the categories of use I and II corresponding to impact energies of $60 \mathrm{Nm}$ (use category I) and $120 \mathrm{Nm}$ (use categories II), respectively (see Table 5). In this case, three impacts were considered for each impact loading.

The safety in use impact resistance was obtained for the same categories as the serviceability impact resistance (I and II), but with impact energies of 100 and $200 \mathrm{Nm}$, respectively.

For the serviceability tests, the hard body impact was applied with the steel sphere of $0.5 \mathrm{~kg}$, involving impact energy of $2.5 \mathrm{Nm}$ (Zones I and II). For safety in use, the steel sphere of $1 \mathrm{~kg}$ was used and impact energy of $10 \mathrm{Nm}$ was considered.
The criteria used in the assessment of the performance of the partition after impact was: 1) no collapse, meaning that the walls should maintain its integrity and still capable of carrying out the own weight in the test position; 2) no penetration, meaning that the bag should not pass through the partitions; 3 ) no projection, which means that no disintegration of material occurs by avoiding the possible occurrence of sharp cutting edges.

For measuring the deformation of the walls during impact loading, a marker was positioned in the zone of impact for measurement of deformations (Figure 3 to 5). The values of deformations corresponding to each impact and the permanent deformations are later indicated in Table 5 , for all tests considered.
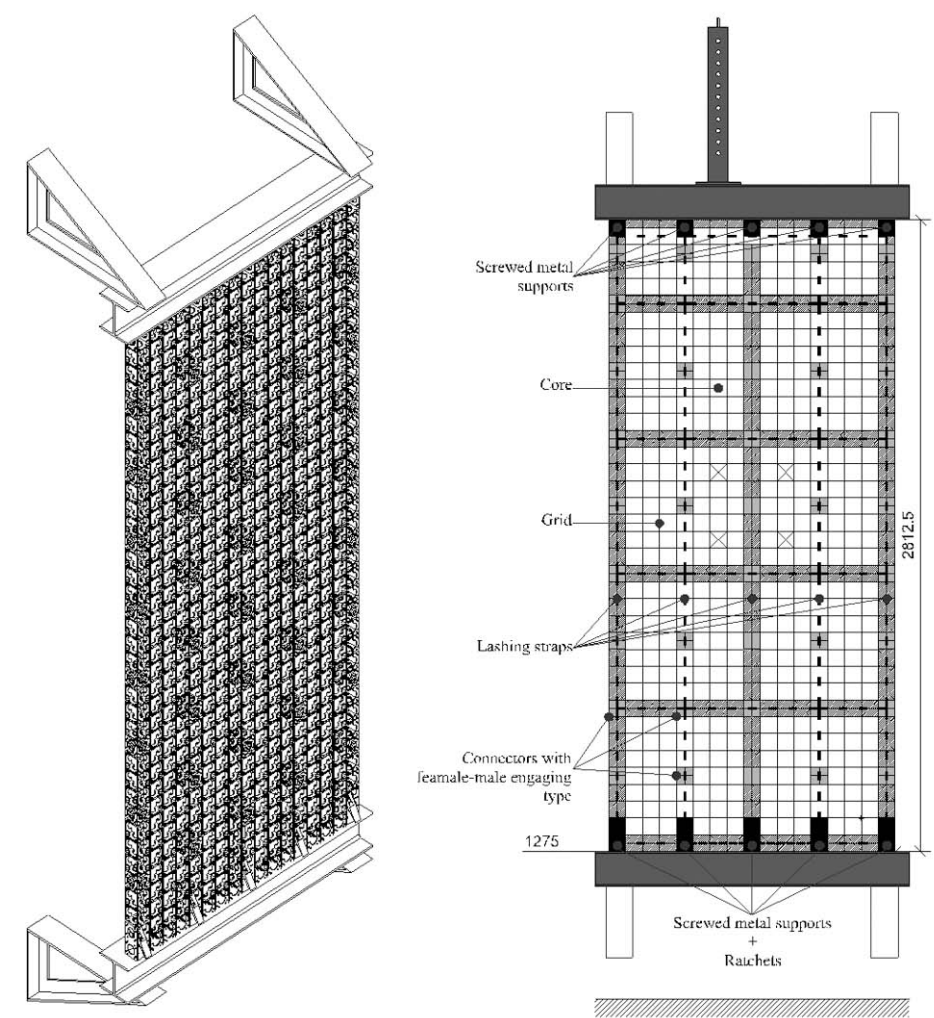

Front view

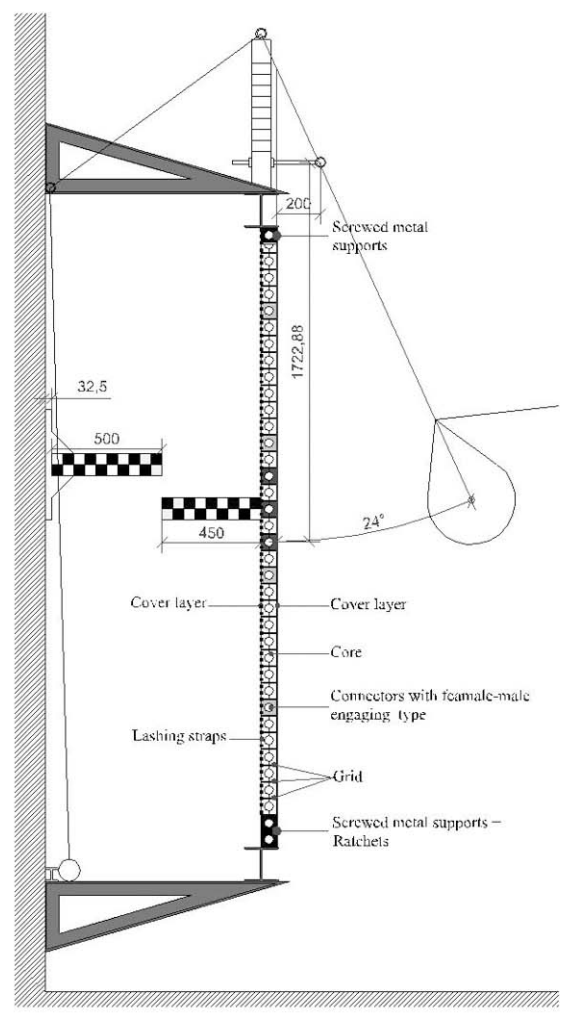

Side view

Figure 3. Test setup for impact tests. Axonometric, front and side view drawings of laboratorial prototype. Indication of the impact zone point.

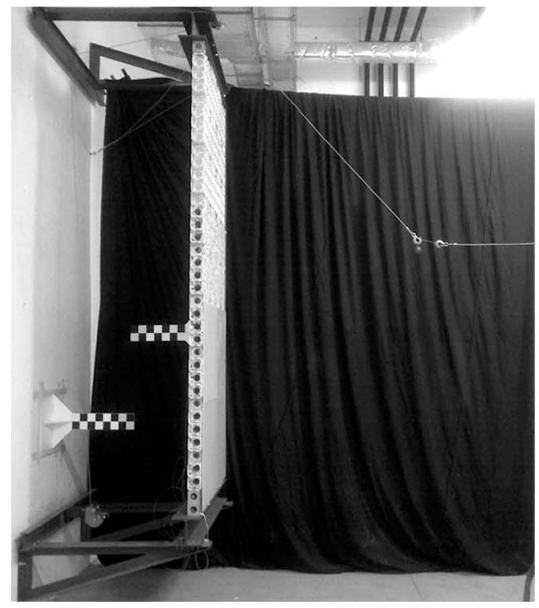

(a)

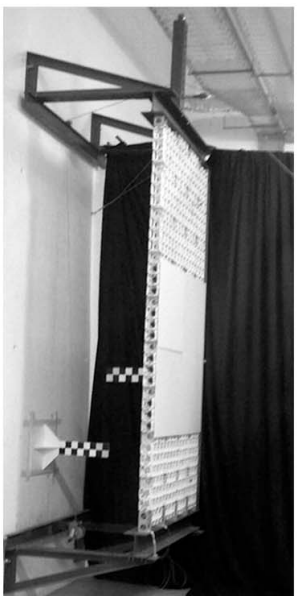

(b)

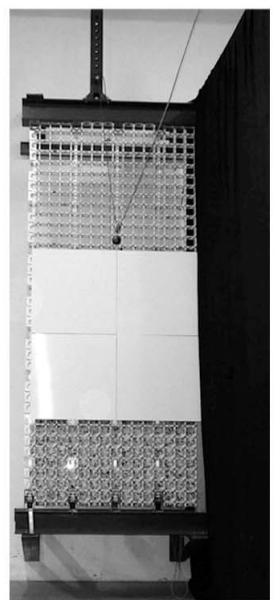

(c)

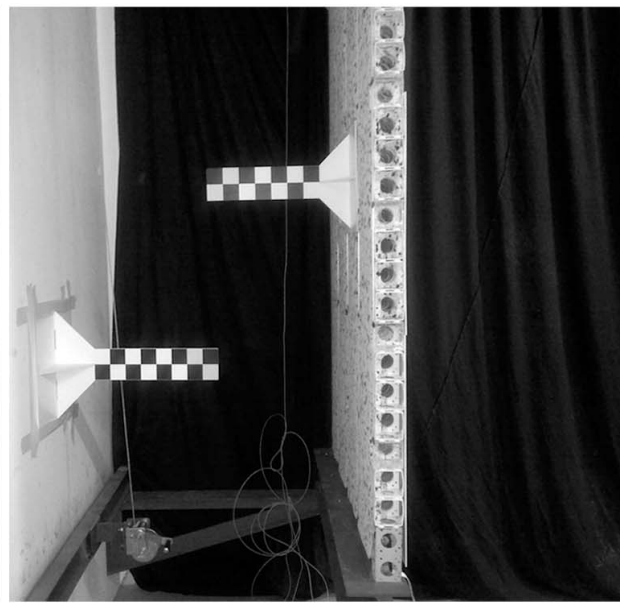

(d)

Figure 4. Preparation of the impact test setup. 
The tests were recorded with two full HD video cameras $(1920 \times 1080$ pixels a t25 frames per second): one to film the side view and another to film the front view (see Figure 4). Then, images showing the maximum detachment of laboratorial prototype in each impact test were captured based on video images. The images were captured with the computer tool GOM Player®. After capturing the images, through a computer aided design tool, guiding lines were designed over the reference scale rules accurately determine the displacement.

\section{RESULTS AND DISCUSSION}

As mention previously, the impact tests for different coating material and substructure were captured with a camera. The impact test was recorded from two directions: side and front view. Table 4 shows the initial position of the specimen and the maximum displacement of it from side view. Values of deformations corresponding to the impact and the permanent deformations are indicated in Table 5 for the serviceability tests carried out.

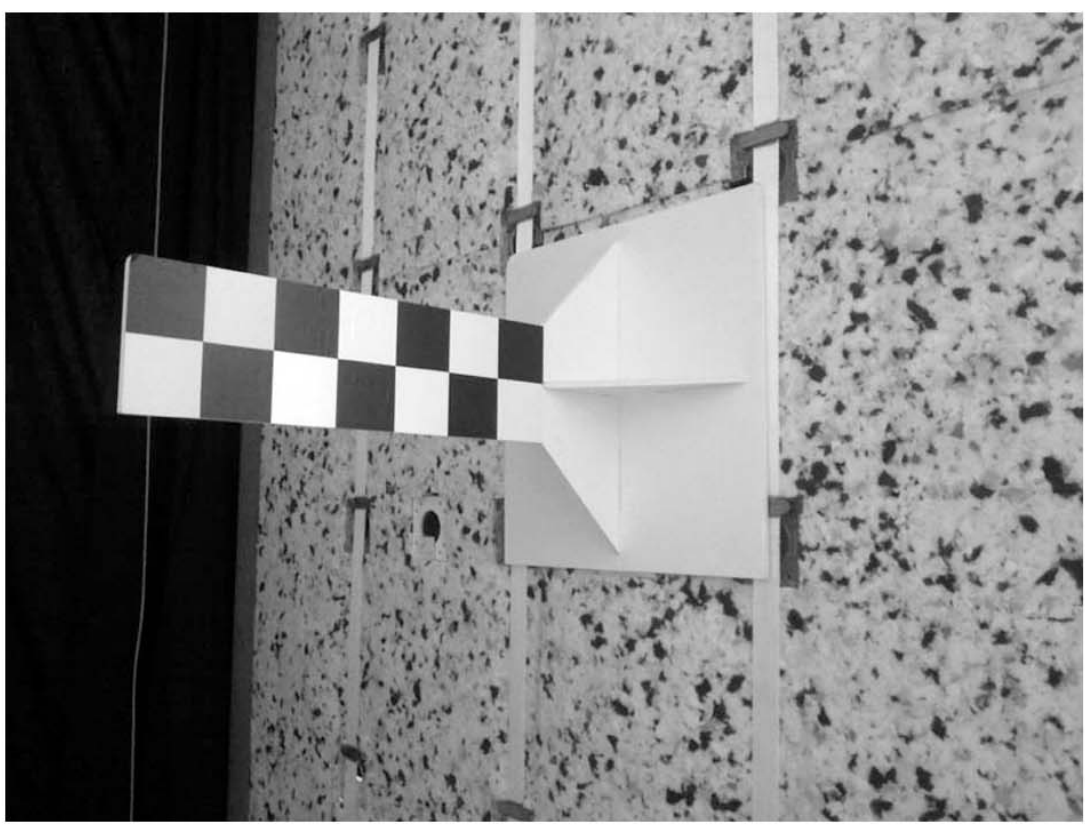

(a)

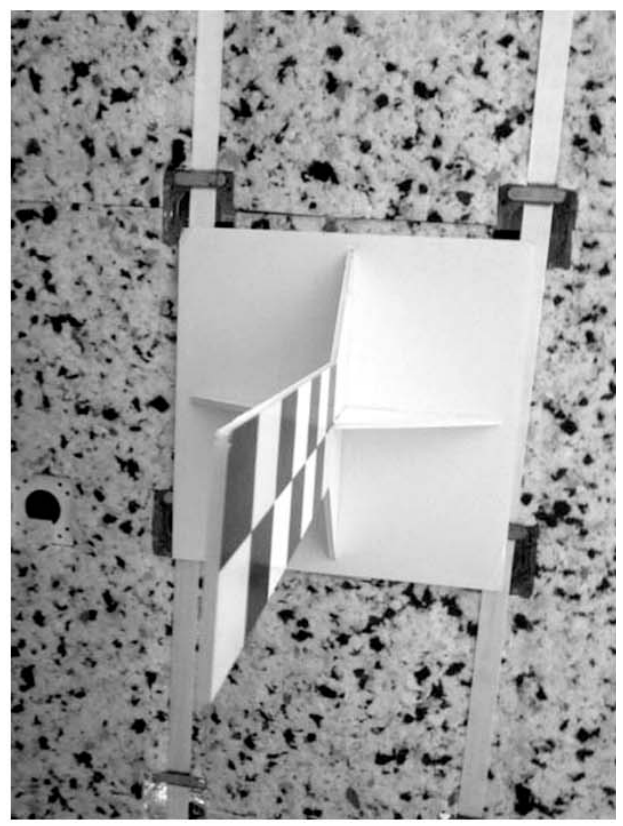

(b)

Figure 5. Reference scale rules to measure the out-of-plane deformation of the wall due to the impacts.

Table 4. Test overview to determine serviceability and safety in use conditions under impact loads.

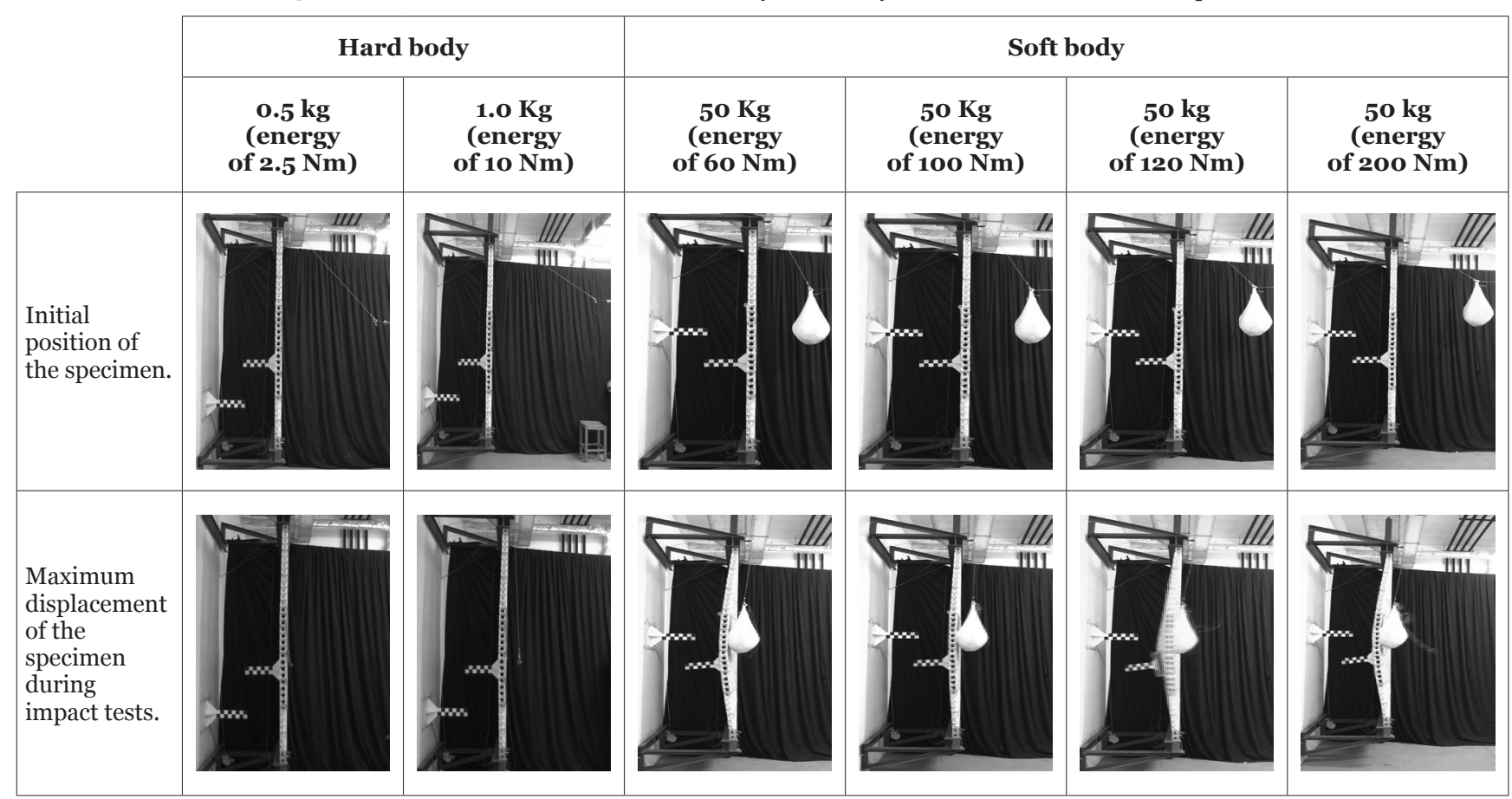




\subsection{Serviceability results}

The laboratorial prototype was used to evaluate the mechanical behaviour of the AdjustMembrane solution. The values of deformations corresponding to the impact and the permanent deformations are indicated in Table 5 , for the serviceability tests carried out.

The visual inspection made at the level of the interfaces between the wall and the steel frame revealed the absence of any separation. The safety criteria of no collapse, no penetration and no projection were thus fully accomplished according to (5) and (13), being the partitions in perfect condition of use after the different phases of loading. Notice that due to the absence of damage, it was decided to make all tests using the same prototype.

It is observed that the partition presents a good behaviour under distinct soft body impact energies, which is confirmed by no permanent deformation and the verification of the criteria needed to be found and that correspond to the global integrity of the wall after impact tests (see Table 5). The deformation increased with the increase on the impact energy, but in all cases was lower than the limit mentioned in (5). No permanent deformation was recorded both for the safety in use and serviceability conditions. It was also observed that no increment on the deformation was recorded after the successive impacts.

During impact tests, no damage was observed, neither on the structure or the coating. After impact, the specimen returned to the original position without residual displacements, with the exception of the tensioned straps on the soft body impact test with $120 \mathrm{Nm}$ energy. In this case, it was visible a maximum displacement (slipping) of $5 \mathrm{~mm}$ (top to bottom) of the $2^{\text {nd }}$ and $3^{\text {rd }}$ strap (from left to right), as can be seen in Figure 6.

Based on the results obtained for impact loads, it should be concluded that the partition solution proposed here is appropriated to resist impact loads, both corresponding to the projection of objects and collision of users.

\section{CONCLUSIONS}

This paper presents and discusses the results of the service and use conditions tests of an innovative solution for partition walls, designated AdjustMembrane developed within a research project at University of Minho, Portugal. After a general presentation of the wall technology, the results of impact tests are presented and discussed. This study contributed to the optimization of AdjustMembrane system.

According to the impact tests, the solution has good mechanical properties and high ductility and deformability, since the impact resistance tests were successfully achieved. The walls presented no collapse, no penetration and no projection with energy equal to $10 \mathrm{Nm}$ with hard body, and $200 \mathrm{Nm}$ with soft body, for the safety in use category II - zones or areas with little risk of accidents. In terms of serviceability it resisted to soft body impact of

Table 5. Serviceability and safety in use impact loads resistance according with (5) (15).

\begin{tabular}{|c|c|c|c|c|c|c|}
\hline & $\begin{array}{c}\text { Mass } \\
\text { [Kg] }\end{array}$ & Zones & $\begin{array}{c}\text { [1] Energy } \\
\text { [Nm] }\end{array}$ & $\begin{array}{l}\text { Number } \\
\text { of impacts }\end{array}$ & $\begin{array}{c}\text { Average } \\
\text { Deflection } \\
{[\mathrm{mm}]}\end{array}$ & $\begin{array}{c}\text { Residual } \\
\text { deflection } \\
\text { [mm] }\end{array}$ \\
\hline \multirow{4}{*}{ 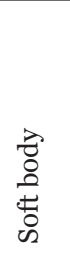 } & 50 & I & 60 & \multirow{2}{*}{3} & $\begin{array}{c}127 \\
(124,133,124)\end{array}$ & o \\
\hline & 50 & II & 120 & & $\begin{array}{c}191 \\
(186,191,197)\end{array}$ & $\mathrm{O}$ \\
\hline & 50 & I & 100 & 1 & 100 & o \\
\hline & 50 & II & 200 & 1 & 150 & $\mathrm{O}$ \\
\hline \multirow{2}{*}{ 胥 } & 0.5 & I and II & 2.5 & 1 & 13 & $\mathrm{O}$ \\
\hline & 1.0 & I and II & 10 & 1 & 20 & o \\
\hline
\end{tabular}
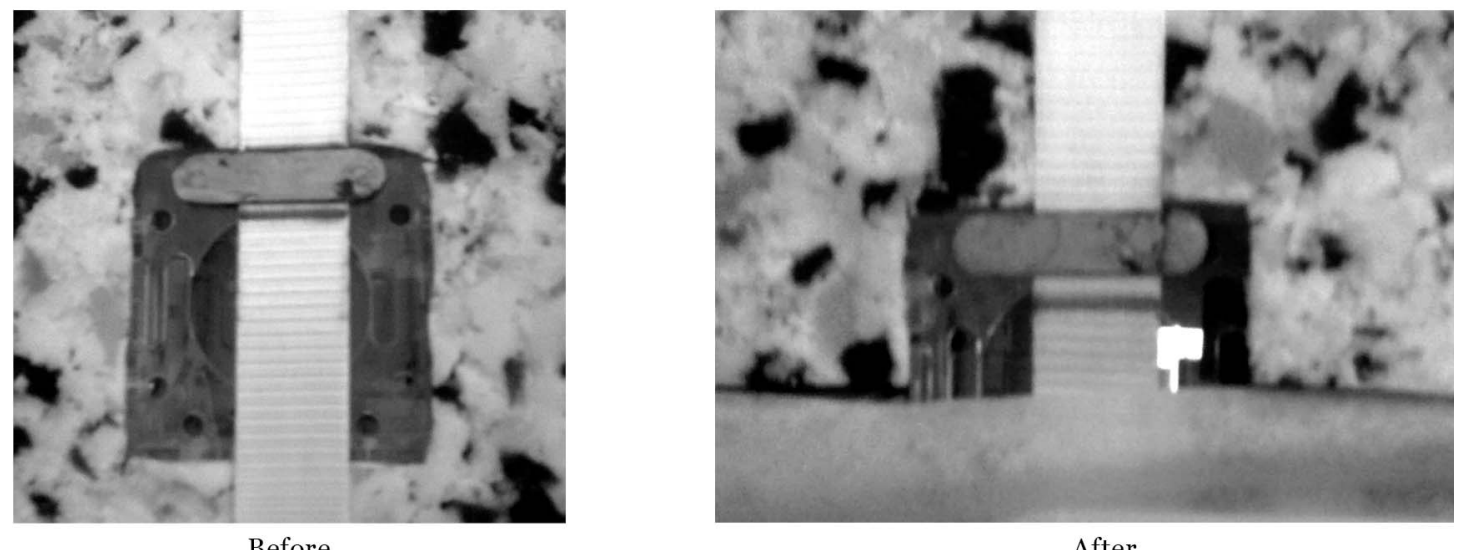

Figure 6. Deformations for soft body impact. Small displacement (slipping) of straps resulted from soft body impact. Impact test with soft body $(50 \mathrm{~kg})$ and energy of $120 \mathrm{Nm}$. 
$120 \mathrm{Nm}$ and Hard body of 2.5 Nm with no penetration and no projection. From the obtained results, it was possible to conclude that the AdjustMembrane partition kit solution fulfils the requirements of mechanical stability in terms of resistance to hard-body and soft-body impacts in terms of safety in use and serviceability adequate for housing and office buildings.

\section{ACKNOWLEDGEMENTS}

The authors wish to thank FCT (Fundação para a Ciência e Tecnologia - Portugal) and COMPETE (Programa Operacional de Fatores de Competitividade - Portugal) for supporting the project with the reference PTDC/AURAQI/102321/2008.

\section{REFERENCES}

(1) Coelho, A., Cabrita, A. (2003). Habitação evolutiva e Adaptável (Prologue). Lisbon: LNEC - Informações Científicas e Técnicas de Arquitetura, ITA 9.

(2) Gausa, M. (1998). Housing: Nuevas Alternativas, Nuevos Sistemas. Barcelona: Actar Publishers.

(3) Horden, R. (1995). Light Tech, Towards a light Architecture. Berlin: Birkhäuser Verlag.

(4) Slessor, C. (1997). Eco-tech: sustainable architecture and high technology. New York: Thames and Hudson.

(5) EOTA. (1998). ETAG oo3: Guideline for European technical approval for internal partition kits for use as non-loadbearing wall. European Organisation for Technical Approvals.

(6) Addis, W., Schouten, J. (2004). Principles of design for deconstruction to facilitate reuse and recycling. London: CIRIA.

(7) Faria, J. (1996). Divisórias Leves prefabricadas - conceção e avaliação da viabilidade de um sistema realizado com base em madeira e derivados (Ph.D. Thesis), p. 54. Oporto: University of Oporto - Civil Engineering.

(8) Macieira, M. (2012). Architectural Membranes: Potential application in the interior of buildings (MSc thesis). Guimarães: University of Minho - School of Architecture.

(9) Mateus, R., Macieira, M., Mendonça, P., Bragança, L. (2011, 18-21 October). Life-cycle Assessment of Different Building Technologies for Partition Walls - contribution to future developments on interior partition concepts. In Proceedings of SB 11 - World Sustainable Building Conference. Helsinki, Finland.

(10) Mendonça, P., Macieira, M. (2012, 12-14 February). Interior partition walls in Mediterranean climates - lightweight versus heavyweight. In Proceedings of International Conference Sustainable Environment in the Mediterranean Region: from Housing to Urban and Land Scale Construction. Naples, Italy.

(11) Mateus, R., Neiva, S., Bragança, L., Mendonça, P., Macieira, M. (2013). Sustainability assessment of an innovative lightweight building technology for partition walls - comparison with conventional technologies. Building and Environment, 67: 147-159, doi: http://dx.doi.org/10.1016/j.buildenv.2013.05.012.

(12) CEN. (2001). EN 1991-1-1 - Eurocode 1: Actions on structures - Part 1-1: general actions - densities, self-weight, imposed loads for buildings. European Committee for Standardization.

(13) EOTA. (2003). Determination of impact resistance of panels and panel assemblies. Technical report TR oo1. European Organisation for Technical Approvals.

(14) Vasconcelos, G., Lourenço, P., Mendonça, P., Camões, A., Mateus, R., Bragança, L. Brito, A., Poletti, E. (2013). Proposal of an innovative solution for partition walls: mechanical, thermal and acoustic validation. Construction and Building Materials, 48: 961-979, doi: http://dx.doi.org/10.1016/j.conbuildmat.2013.07.079.

(15) ISO. (1988). ISO 7892:1988 - Vertical Building Components - Impact resistance - Impact Bodies and General Test Procedures. International Organization for Standardization.

(16) ISO. (1990).ISO/DIS 7893:199o. Performance Standards in Building - Partitions made from components - Impact resistance tests. International Organization for Standardization. 